\title{
Japanese spiders of the genus Agelena (Araneae: Agelenidae)
}

\author{
Akio Tanikawa \\ Laboratory of Biodiversity Science, School of Agriculture and Life Sciences, \\ The University of Tokyo, 1-1-1, Yayoi, Bunkyo-ku, Tokyo, 113-8657 Japan \\ E-mail:dp7a-tnkw@j.asahi-net.or.jp
}

\begin{abstract}
The Japanese spiders of the genus Agelena are revised. The occurrence of A. limbata Thorell 1897, A. opulenta Koch 1878, and A. labylinthica (Clerck 1757) are recomfirmed. A. donggukensis Kim 1996 is newly recorded from Japan and the male of the species is described for the first time. A new species, $A$. babai, is described based on the specimens collected from Amami-ôshima Is. of the Ryukyus.
\end{abstract}

Key words - taxonomy, Agelena limbata, Agelena opulenta, Agelena labylynthica, Agelena donggukensis, Agelena babai n. sp.

The study on Japanese spiders of the genus Agelena was started by the description of Agelena opulenta Koch 1878, followed by the description of Agelena japonica Karsch 1879. The first monograph of Japanese spiders entitled Japanische Spinnen by Bösenberg \& Strand (1906) included six species of Agelena, that is, A. limbata Thorell 1897 (new record), A. tubicola Bösenberg \& Strend 1906 (new species), A. opulenta, A. japonica, A. ignota (new species, transferred to Coelotes), and $A$. labyrinthica (doubtful record). After that, Yaginuma (1958) confirmed $A$. labyrinthica (Clerck 1757) to be occurring in Japan, and Lehtinen (1967) synonymized $A$. japonica with $A$. opulenta, and $A$. tubicola with $A$. labyrinthica. Thus three species, labyrinthica, limbata, and opulenta, have been known from Japan as spiders belonging to the genus Agelena (Tanikawa 2000).

After examining many spider specimens collected from various parts of Japan, I recognized five species of the genus, that is, A. labyrinthica, A. limbata, A. opulenta, A. donggukensis Kim 1996 and an undescribed species. $A$. donggukensis will be newly recorded from Japan, and its male will be described for the first time. An undescribed species will be described as a new species under the name A. babai. At the same time, through the examination of the type specimens, I reconfirmed the synonymy of $A$. japonica with $A$. opulenta, and $A$. tubicola with $A$. labyrinthica.

The type specimens designated in this paper are deposited in the collection of the Department of Zoology, National Science Museum, Tokyo (NSMT). For some of the species of Agelena (e.g. A. limbata), many literature records have been accumulated from various areas of Japan. However, I listed only islands from which occurrence of the species was confirmed by my own examination of the specimens or illustration, photos appeared in the literature in "Distribution". All the specimens examined in this study were collected by the author unless otherwise noted.

Taxonomy

Family Agelenidae C. L. Koch 1837

Genus Agelena Walckenaer 1805

Agelena limbata Thorell 1897

[Japanese name: Kusa-gumo]

(Figs. 1-2, 11-14, 23-25, 28-29, 31-32)

Agalena limbata Thorell 1897, p. 255 [type not examined]. Agelena limbata: Bösenberg \& Strand 1906, p. 296, pl. 8, fig. 104, pl. 16, fig. 461; Saito 1939, p. 63, fig. 8.3; Saito 1959, p. 37, pl. 1, figs. $13 b^{-}$c, pl. 2. fig. 13a; Yaginuma 1960 , p. 91 , pl. 42, fig. 238, text-figs. 81.2, 7; Paik 1978, p. 322, fig. 141; Yaginuma 1985, p. 121, figs. 1-2; Yaginuma 1986, p. 138, pl. 40, fig. 1, text-figs. 73.1, 75.1-30; Chikuni 1989, p. 98, fig. 1; Song, Zhu \& Chen 1999, p. 354, figs. 205H (misprinted in the text as 205I), 206H, 207B; Kim \& Tak 2001, p. 121, figs. 7ae; Namkung 2002, p. 357, unnumbered figures.

Specimens examined. MIYAGI PREF.: Lake Izunuma, Hasama-cho, 1우, became adult female on 22-VII-1987 after rearing from egg collected in autumn 1986 (NSMT-Ar $5621)$; 20, 10-VIII-1986; 1우, 20-VIII-1986; 1우, 24-IV1986; 3우, 15-IX-1987 (1우: NSMT-Ar 5622). IBARAKI PREF.: Tsukuba-shi, 1우, 13-IX-1977. TOCHIGI PREF.: Forest Park, Utsunomiya-shi, 2우주, 12-VIII-1990. GUNMA PREF.: Tokura, Katashina-mura, 1우, 30-VII1987. SAITAMA PREF.: Kinchaku-den, Hidaka-shi, 1ð, 14-VII-1991; 1우, 13-X-1991. CHIBA PREF.: Sanbu-cho, Sanbu-gun, 1o, 28-VII-1992. TOKYO: Hachiôji-jôshi, Hachiôji-shi, 1ð, 16-VII-1989. KANAGAWA PREF.: Near Soubudai-shita Station, Sagamihara-shi, 1우1ð, 7-VII2004; Tsukimino, Yamato-shi, 1우, 24-X-1993; Izuminomori, Yamato-shi, 1우, 30-VIII-1993; Kamiwada, Yamato- 


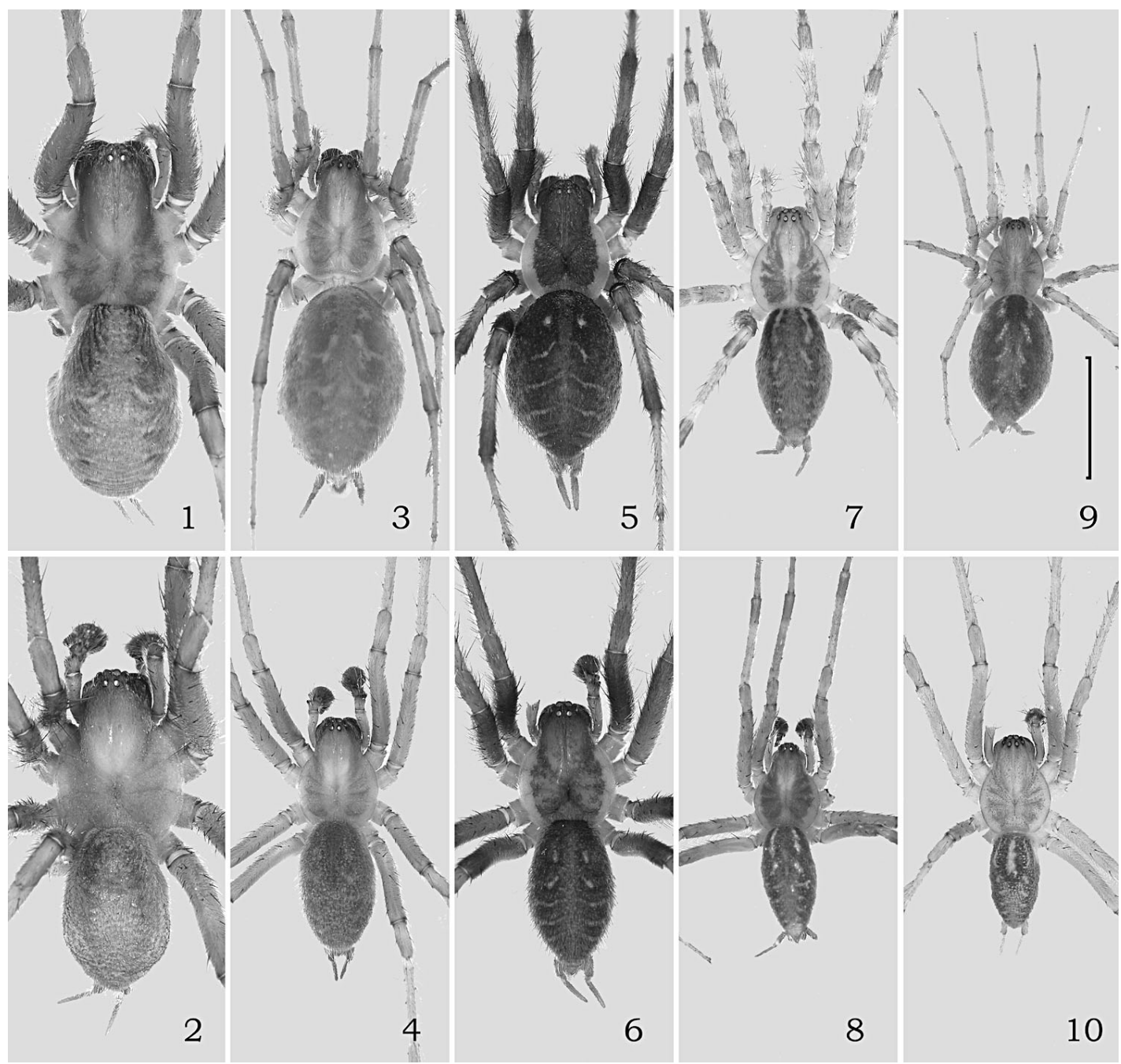

Figs. 1-10. Habitus, odd number female, even number male. - 1-2, Agelena limbata (Thorell 1897)(NSMT-Ar 5622, 5630); 3-4, A. labyrinthica (Clerck 1757)(NSMT-Ar 5636-5637); 5-6, A. babai new species (holotype, NSMT-Ar 5645, paratype, NSMT-Ar 5650); 78, A. opulenta Koch 1878 (NSMT-Ar 5658, 5654); 9-10, A. donggukensis Kim 1996 (NSMT-Ar 5664, 5666). (Scale: 5mm)

shi, 1우, 2-VIII-1993; Noba-cho, Yokohama-shi, 20, 10VII-1980, M. Mori leg. (10': NSMT-Ar 5623); Yôkôdai, Yokohama-shi, 1우, 23-IX-1998; Sakae-ku, Yokohama-shi, 1우, 23-IX-1998 (NSMT-Ar 5624); Anjinzuka, Yokosuka-

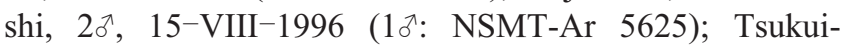
shiroyama, Tsukui-macni, 1우, 23-IX-1984; 1우, 20-X1985; Tanzawa, 1우 $10-\mathrm{X}-1982 ;$ 1ㅇ, 28-X-1984. NAGANO PREF.: Alps Park, Matsumoto-shi, 3우고, 9VIII-1990 (1우 $1^{\Uparrow}$ : NSMT-Ar 5626-5627). YAMANASHI PREF.: Masuho-cho, 1우, 24-VII-2004. SHIZUOKA PREF.: Yugashima, Izu-shi, 1ð, 21-VIII-1990; Minamiizucho, Kamo-gun, 1우, 19-X-1986; 10, 25-VII-1992; Shimoda-shi, 1우1 주, 15-VIII-1978; 2우추, 3-VIII-1980; 1 우, 13-VIII-1980 (NSMT-Ar 5628); 1우, 7-VIII-1980. AICHI PREF: Atsumi-cho, Atsumi-gun, 1우1 $0^{\lambda}, 25^{-} \mathrm{VIII}^{-}$ 1993; MIE PREF.: Kiwa-cho, Minamimuro-gun, 1우1주, 3VIII-1991; Kumano-shi, 1우1 ${ }^{\star}, 26^{-}$VII-1993; detail uncertain, 4우, 20-VIII-1980 (1우: NSMT-Ar 5629); 1우, 13-VIII1981, A. Uyemura leg. WAKAYAMA PREF.: Kokonoe,
Koyaguchi-cho, 1ㅇ, 28-VIII-1990; Nachikatsuura-cho, Higashimuro-gun, 1우, 2-VIII-1991, 1우, 4-VIII-1991; Kushimoto-cho, Nishimuro-gun, 1ð, 23-VIII-1993; Ataka, Hiokigawa-cho, 1ㅇ, 31-VIII-1990; Mihama-cho, Hidakagun, 1우, 29-VIII-1990. TOTTORI PREF.: Jûbô, Shikanocho, Ketaka-gun, 1우, 20-IX-1987, N. Tsurusaki leg.. OKAYAMA PREF.: Okuichi, Okayama-shi, 5웇ㄲ, 25VIII-1991 (10 ${ }^{\lambda}$, NSMT-Ar 5630); Higashitaichi, Tamanoshi, 1ㅇ, 26-VIII-1991. HIROSHIMA PREF.: Onomichishi, 1우, 23-IX-1992. YAMAGUCHI PREF.: Hagi-shi, 1우, 23-IX-1982; Sakamizu, Shûhô-cho, Mine-gun, 1우, 2-VIII1990, N. Tsurusaki leg. FUKUOKA PREF.: Hisayama-cho, Kasuya-gun, 2ㅇ, 24-VIII-1991. MIYAZAKI PREF.: Miyazaki Jingu, Miyazaki-shi, 10, 18-VIII-1989, KAGOSHIMA PREF.: Sendai, Kokubu-shi, 7우숭, 23VIII-1989; Fukiage-hama, Higashi-ichiki-cho, 1우, 22VIII-1989; detail uncertain, 10, VIII-1985. YAKUSHIMA IS.: Miyanoura, 30 15-VII-1990, Kusukawa, 1, 17-VII1990 (NSMT-Ar 5631), Yudomari, 10, 17-VII-1990 
(NSMT-Ar 5632). OKINAWA PREF, IRIOMOTEJIMA IS.: Urauchi, 1우, 16-VIII-1985; 1우, 7-VIII-1987; Funaura, 1우, 19-VIII-1985, 2juv. (became adult males on 24-VI1989 after rearing), 29-III-1989; Omija, 2juv., 2-V-1990 (became adult males on 27-VI-1990 after rearing); Komi, 1 우 16-VIII-1985, 2juv. (became adult female and male on 4-VII-1987 after rearing), 27-III-1987; 2우, 13-VIII-1987;
1우, 6-VIII-1987; 1juv. (became adult female on 13-VII1990 after rearing), 3-V-1990; 1우, 25-VII-1991; Otomi, 1 우, 19-VIII-1988; 4juv. (became two adult females and two males on 30-VI-1990 after rearing), 30-IV-1990; 1우, 23VII-1991; 6우1ð, 27-VI-2004 (1우: NSMT-Ar 5633); Ohara, 1우, 12-VIII-1985; 1우, 24-VII-1991; 1우, 12-VIII1992; 1juv. (became adult female on 4-VII-1987 after rear-
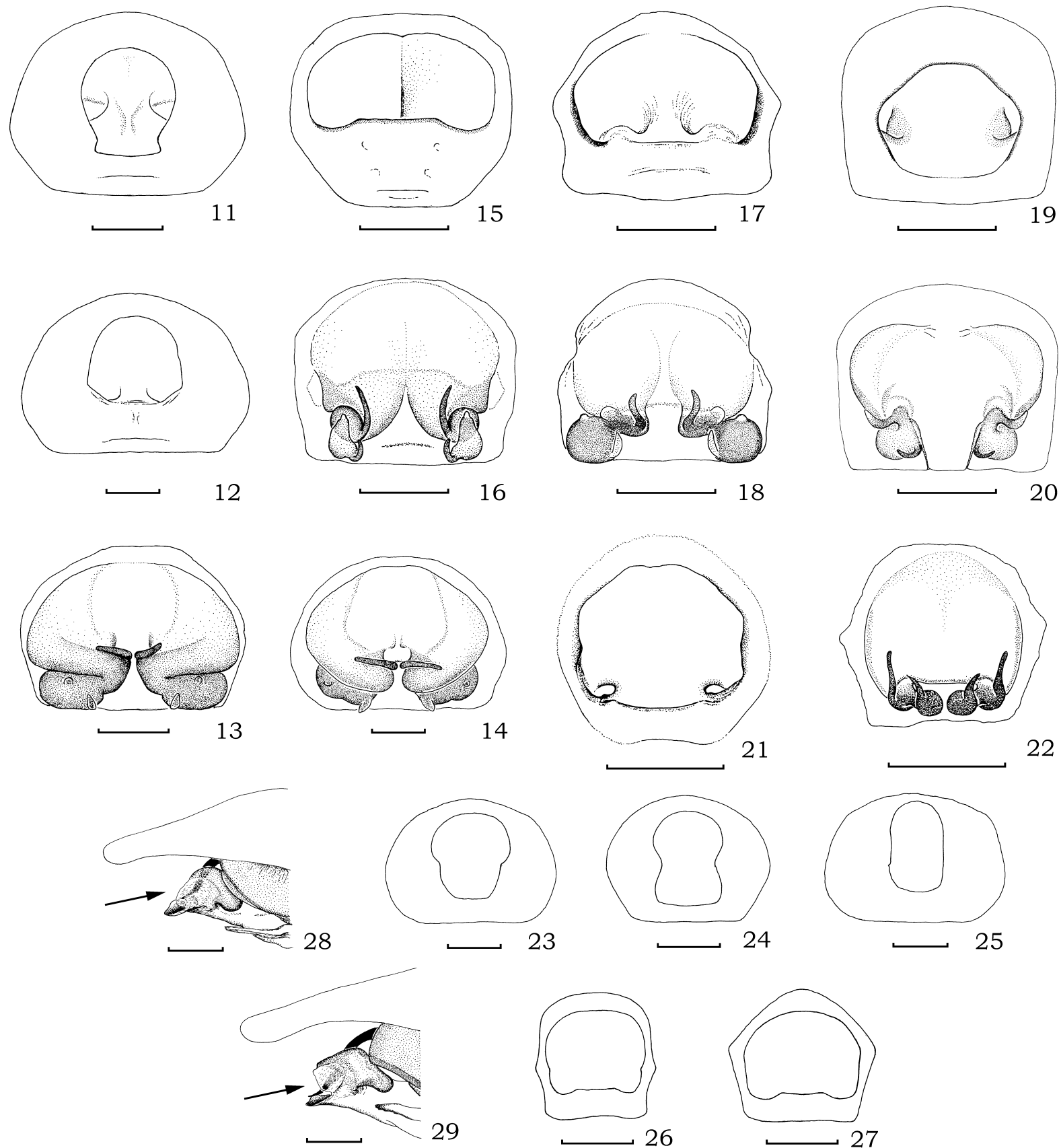

29
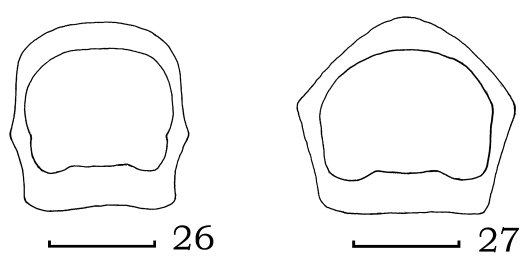

Figs. 11-29. Genital organ. - 11-12, 15, 17, 19, 21, 23-27, epigynum ventral view; 13-14, 16, 18, 20, 22, same dorsal view; 28-29, male palp apical part lateral view. 11-14, 23-25, 28-29, Agelena limbata (Thorell 1897)(11, 13, Shizuoka Pref., NSMT-Ar 5628; 12, 14, Iriomotejima Is., NSMT-Ar 5633; 23, Mie Pref., NSMT-Ar 5629; 24, Miyagi Pref., NSMT-Ar 5621; 25, Yakushima Is., NSMT-Ar 5631; 28, Yokohama, NSMT-Ar 5623; 29, Iriomotejima Is., NSMT-Ar 5634. 15-16, A. labyrinthica (Clerck 1757), NSMT-Ar 5641. 17-18, A. babai new species, NSMT-Ar 5645. 19-20, A. opulenta Koch 1878, NSMT-Ar 5658. 21-22, 26-27, A. donggukensis Kim 1996, NSMT-Ar $5671,5664,5665,5672$. Arrows indicate a difference between the Yaeyama populations and the other populations in Japan of A. limbata. (Scales: $0.5 \mathrm{~mm}$ ) 
ing), 27-III-1987; 1juv. (became adult male on 13-VI1987), 1-IV-1987 (NSMT-Ar 5634). YONAGUNIJIMA IS.: Mt. Kuburadake, 5우즈, 22-VI-2004.

Description. Measurements (in $\mathrm{mm}$ ). Based on 1 우 from Miyagi Pref. (NSMT-Ar 5622) and $10^{\Uparrow}$ from Okayama Pref. (NSMT-Ar 5630); measurements in parentheses indicate the range among specimens. Body +914.75 (11.2518.50), ग $^{1} 13.75$ (8.90-17.7) long. Carapace 7.67 (5.597.67), 377.50 (4.27-8.00) long; 우5.33 (3.82-5.90), ${ }^{5} 5.75$ (3.23-6.17) wide. Length of legs [female/male; tarsus + metatarsus + tibia + patella + femur $=$ total]: $\mathrm{I}, 2.67+5.73+$ $5.40+2.47+6.53=22.80 / 3.60+9.20+7.70+2.80+8.50$ $=31.80$; II, $2.47+5.27+4.87+2.47+6.20=21.28 / 3.70+$ $8.80+4.10+2.70+8.10=30.40 ;$ III, $2.27+5.20+4.20+$ $2.27+5.73=19.67 / 3.20+8.10+5.80+2.30+7.50=$ $26.90 ;$ IV, $2.87+7.33+5.73+2.40+7.20=25.53 / 3.70$ $+1.10+7.50+2.60+8.90=33.80$. Abdomen 우7.92 (6.0011.50), 377.08 (4.50-9.60) long; 우5.58 (3.87-8.13), 3 3.69 (2.91-5.20) wide.

Female and male. Carapace longer than wide [length/ width 우1.44 (1.29-1.46), o $1.30\left(1.30^{-1.38)}\right.$ ]. Median ocular area longer then wide [length/width 우1.16 (1.09-1.17), o $1.15(1.14-1.19)]$; almost as wide in front as behind [anterior width/posterior width $90.95(0.94-1.00)$, o $1.04(0.97-$ 1.09)]. Promargin of fang furrow of chelicera with 3 teeth, retromargin with $3(3-4)$ teeth. Labium wider than long [length/width 우0.93 (0.83-0.96), ठ0.94 (0.84-1.04)]. Sternum longer than wide [length/width 우1.09 (1.08-1.14), ${ }^{3} 1.08\left(1.05^{-1.16)}\right]$. Length of leg $\mathrm{I} /$ length of carapace +2.97 (2.97-3.34), o 4.24 (3.93-4.39). Male palp (Figs. 28-29, 3132): embolus originates at 8 o'clock position in ventral view (Fig. 31, arrow). Abdomen longer than wide [length/width 우.42 (1.42-1.60), o 1.51 (1.51-1.85)]. Epigynum: opening longer than wide (shape much varied among specimens as shown in Figs. 11-12, 23-25), dorsal view as shown in Figs. 13-14.

Coloration and markings. Female and male (Figs. 1-2). Carapace yellow with a pair of dark brown longitudinal lateral band. Dorsum of abdomen brown with a pair of dark brown longitudinal lateral bands including light colored markings.

Remarks. Agelena limbata closely resembles $A$. labyrinthica in general appearance. But they can be easily separated by the shapes of epigynum and male palpal organ. Although epiginal openings of limbata are much varied, all of them are longer than wide (Figs. 11-12, 23-25), in contrast, those of labyrinthica are wider than long (Fig. 15). Embolus of limbata originates at the 8 o'clock position in ventral view (Fig. 31, arrow), but in labyrinthica it originates at the 9 o'clock position (Fig. 33, arrow).

Distribution. Japan (Hokkaido, Honshu, Shikoku, Kyushu, and the Yaeyama Isls.), Myanmar, China, Korea.

Notes. Agelena limbata is distributed widely from Myanmar to Japan, but is not found from the Amami Isls. and the Okinawa Isls, South West Japan. It was recorded from Taiwan only once (Li 1964), but the voucher specimen has been lost. Probably this species does not live in Taiwan (Yaginuma 1985, Lee 1998). Thus the population of limbata of the Yaeyama Isls, the most southwestern part of Japan, is isolated from the populations of the other regions. The specimens of Yaeyama can be distinguished by the shape of epiginal opening and palpal organ from the specimens of other regions. The shapes of epigynal openings of the specimens from the Yaeyama Isls. are rounded triangle (Fig. 12) with little variation, while, those of other regions are variable (Figs. 11, 23-25, Yaginuma 1985, fig. 1.1-30), although some of them are similar to those in Yaeyama (Yaginuma 1985, figs. 1.11, 26). In males, Yaeyama specimens can be distinguished from other regions by the shape of conductor in lateral view. The conductor of Yaeyama populations tends to wrap the embolus (Fig. 28, arrow), but not in other regions (Fig. 29, arrow). However, in populations of other regions, there are a few males and females that showed characteristics very similar to those in Yaeyama Isls. This circumstance makes me to conclude that the Yaeyama population is not a different taxon. Closer examinations other than morphology are necessary to clarify the exact taxonomic position of the Yaeyama population.

\section{Agelena labyrinthica (Clerck 1757) \\ [Japanese name: Inazuma-kusa-gumo]}

(Figs. 3-4, 15-16, 33-34)

Araneus labyrinthicus Clerck 1757, p. 79, pl. 2, fig. 8. [type not examined].

Agelena labyrinthica: Blackwall 1861, p. 152, pl. 10, fig. 97; Yaginuma 1958, p. 72, figs. 5-6; Yaginuma 1960, p. 91, pl. 42, fig. 240, text-figs. 81.1, 3, 5; Ishinoda \& Tsukiji 1969, p. 293, fig. 4; Paik 1978, p. 320, figs. 140.1-5; Roberts 1985, p. 156, fig. 68b; Yaginuma 1986, p. 138, pl. 40, fig. 3, text-fig. 73.2; Chikuni 1989, p. 98, fig. 3; Song, Zhu \& Chen 1999, p. 354, figs. 205G-H, 207A; Kim \& Tak 2001, p. 119, figs. 6a ${ }^{-}$ f; Namkung 2002, p. 358, unnumbered figures.

Agelena tubicola Bösenberg \& Strand 1906, p. 297, pl. 16, fig. 472. [holotype, female, from Saga, Japan, preserved in Senckenberg Museum, SMF 4762, examined.]

Specimens examined. HOKKAIDO: Kanayamako Lake, Furano-shi, 3우13, 30-VII-1985; Yamabe, Furanoshi, 2우, 28-VII-1985 (1우: NSMT-Ar 5635); Syunkokutai, Nemuro-shi, 1우1ð, 16-VIII-1986 (NSMT-Ar 5636-5637), 1우1 주, 14-VIII-1986 (1 주: NSMT-Ar 5638); Akkeshi-cho, 3 우, 14-VIII-1986 (NSMT-Ar 5639); Nopporo, Ebetsu-shi, 1 ㅇ, 14-IX-1986, S. Nakano leg.; MIYAGI PREF.: Lake Izunuma, Hasama-cho, 1ㅇ, 21-VIII-1986; 1ภㄱ, 7-VI-1987 (NSMT-Ar 5640). NAGANO PREF.: Sugadaira, Sanadacho, 1우워, 25-VII-1988 (NSMT-Ar 5641-5642); Alps park, Matsumoto-shi, 1우, 9-VIII-1990 (NSMT-Ar 5643); Matsumoto-shi, 1우, 7-VIII-1990; Kirigamine, Suwa-shi, 1 万', 26-29-VII-1986, S. Tazoe leg. (NSMT-Ar 5644). SHIZUOKA PREF.: Shimoda-shi, 1우, 1-VIII-1978. EHIME PREF.: Ohnogahara, Nomura-cho, Seiyo-shi, 10, 
15-VIII-1972, N. Tsurusaki leg.

Description. Measurements (in mm). Based on 1 우 $10^{7}$ from Hokkaido (NSMT-Ar 5636-5637), measurements in parentheses indicate the range among specimens. Body 우 14.00 (10.88-17.13), $0^{7} 10.00\left(9.50^{-11.75)}\right.$ long. Carapace 우5.06 (4.09-7.54), 374.55 (4.52-5.35) long; 우3.59 (3.09$5.46),{ }^{7} 3.40(3.38-4.00)$ wide. Length of legs [female/male; tarsus + metatarsus + tibia + patella + femur $=$ total]: I, 2.24 $+4.06+3.65+1.76+4.53=16.24 / 2.80+5.47+4.67+$ $1.80+5.27=20.01 ; \quad$ II, $2.06+3.82+3.35+1.76+4.35=$ $15.34 / 2.67+5.13+4.27+1.73+5.13=18.93 ;$ III, $1.94+$ $3.94+3.00+1.59+4.12=14.59 / 2.47+5.20+3.80+1.53$ $+4.80=17.80 ;$ IV, $2.35+5.88+4.18+1.71+5.29=$ $19.41 / 2.93+7.20+5.07+1.67+5.80=22.67$. Abdomen 우 8.30 (6.77-10.38), 35.65(5.35-6.38) long; 우5.50 (4.31$6.38)$, o 3.29 (2.47-3.69) wide.

Female and male. Carapace longer than wide [length/ width ㅇ⒈41 (1.32-1.41), 311.34 (1.34-1.41)]. Median ocular area longer than wide [length/width 우1.16 (1.05-1.16), o $1.17(1.14-1.19)]$; almost same width as in front as behind [anterior width/posterior width 우1.00 (0.91-1.05), o 1.00 (0.98-1.03)]. Promargin of chelicera with 3 teeth, retromargin with $94\left(3^{-4}\right), \delta^{3} 3$ teeth. Labium wider than long [length/width $90.80 \quad\left(0.80^{-0.97),} \delta^{\top} 0.84 \quad(0.80-0.86)\right]$. Sternum slightly longer than wide [length/width +1.05 (1.02-1.17), ${ }^{\top} 1.02\left(1.00^{-1.08)}\right.$ ]. Length of leg I/length of carapace 우3.21 (3.20-3.42), $\delta^{3} 4.40\left(4.10^{-4} 457\right)$. Male palp (Figs. 33-34): embolus originates at 9 o'clock position (Fig. 33, arrow). Abdomen longer than wide [length/width 우1.51 (1.51-1.64), ơ1.71 (1.71-2.17)]. Epigynum (Figs. 15-16): opening wider than long.

Coloration and markings. Female and male (Figs. 3-4). Carapace yellow with a pair of dark brown longitudinal lateral band. Dorsum of abdomen brown with a pair of dark brown longitudinal lateral bands including light colored markings.
Remarks. Agelena labyrinthica closely resembles $A$. limbata in general appearance. The discriminating points of these species are shown in remarks of the latter.

Distribution. Japan (Hokkaido, Honshu, Shikoku, Kyushu) to Europe (Palaearctic).

Agelena babai new species

[Japanese name: Amami-kusa-gumo]

(Figs. 5-6, 17-18, 30, 35-36)

Type series. Holotype: 우, Yuwan, Amami-ôshima Is., Kagoshima Pref., 18-VIII-1996 (NSMT-Ar 5645). Paratypes: 3 우, same data as the holotype (NSMT-Ar 5646-

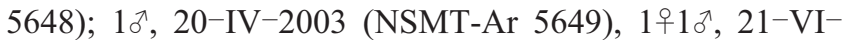
2003 (NSMT-Ar 5650-5651), Yamato-son, Amami-ôshima Is., Kagoshima Pref., Y. G. Baba leg.

Other specimens examined. KAGOSHIMA PREF., AMAMI-ÔSHIMA IS.: 1우, same data as the holotype; Honcha-tôge Pass, 1우 19-VIII-1996; Yamato-son, 2우, 21-VI-2003, Y. G. Baba leg.

Description. Measurements (in $\mathrm{mm}$ ). Based on the holotype +9 and $10^{\lambda}$ from the paratypes (NSMT-Ar 5650), measurements in parentheses for female traits indicate the range among specimens, while those for male traits are the measurements of another specimen. Body + 12.63 (10.2514.63), Љ 11.50 (11.25) long. Carapace ㅇ 5.29 (4.50-6.33), 35.24 (5.47) long; 우4.00 (3.35-4.67), 34.06 (4.12) wide. Length of legs [female/male; tarsus + metatarsus + tibia + patella + femur $=$ total $]: \quad I, 2.06+3.76+3.65+1.94+4.59$ $=16.00 / 2.77+5.69+5.23+2.00+6.00=21.69 ;$ II, $1.94+$ $3.53+3.35+1.94+4.35=15.11 / 2.46+5.38+4.77+2.08$ $+5.77=20.46$; III, $1.82+3.41+2.88+1.76+4.12=$ $13.99 / 2.38+5.15+4.08+1.85+5.23=18.69 ; \mathrm{IV}, 2.12+$ $5.00+4.00+1.82+5.24=18.18 / 2.92+7.08+5.23+1.92$ $+6.38=23.53$. Abdomen 우.75 (5.93-8.60), ${ }^{\top} 6.33$ (5.76) long; ㅇ⒌25 (3.40-6.60), ð3.60 (3.00) wide.

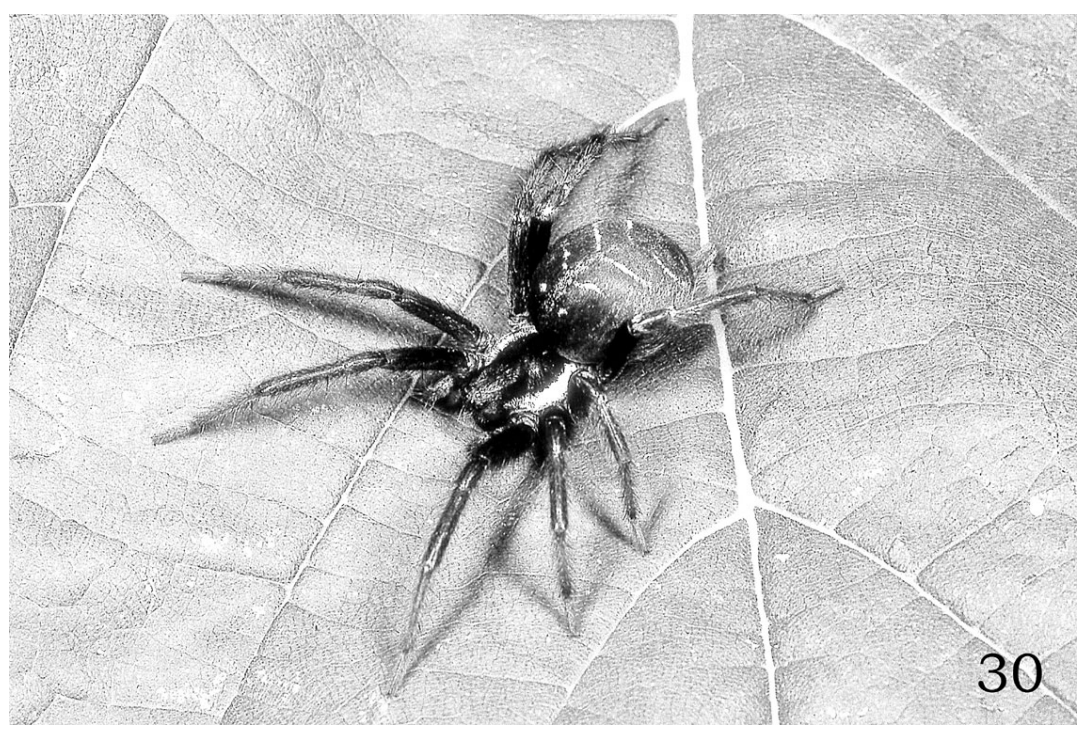

Fig. 30. Agelena babai new species, female on a leaf. 
Female and male. Carapace longer than wide [length/ width 우1.32 (1.29-1.36), o 1.29 (1.33)]. Median ocular area longer than wide [length/width 우1.11 (1.04-1.14), ${ }^{\top} 1.08$ (1.11)]; slightly wider in front than behind [anterior width/ posterior width 우 $1.02(1.02-1.08)$, o $1.12(1.09)]$. Promargin of chelicera with 우 $3(3-4), \delta^{3} 3$ teeth, retromargin with +93 $(3-7), \delta^{3} 4$ teeth. Labium wider than long [length/width 우 $\left.0.82(0.73-0.85), \delta^{\top} 0.75(0.82)\right]$. Sternum almost as long as wide or slightly longer than wide [length/width 우 1.09 (0.92-1.09), ${ }^{\text {t }} 1.06$ (1.06)]. Length of leg I/length of carapace +3.02 (2.83-3.09), $\delta^{7} 4.14$ (3.94). Male palp (Figs. 3536): embolus originates at 9 o'clock position (Fig. 35, arrow). Abdomen longer than wide [length/width o 1.48 (1.30-1.75), ${ }^{\top} 1.76$ (1.92)]. Epigynum (Figs. 17-18): opening wider than long.

Coloration and markings. Female and male (Figs. 5-6). Carapace dark brown with white border. Dorsum of abdomen dark brown with light colored markings.

Remarks. Agelena babai closely resembles A. tungchis
Lee 1998 in general appearance, but can be easily distinguished from the latter by the shape of female genital organ. The epiginal opening is much wider than long in babai (Fig. 17), but slightly wider than long in tungchis. (Lee 1998, fig. 2). The tube attached to spermatheca of babai is short and normal Agelena-type (Fig. 18), but that of tungchis is very long and arched (Lee 1998, fig. 3).

Etymology: The specific name is dedicated to Mr. Yuki G. Baba, the University of Tokyo, who collected the paratypes.

Distribution. Japan (Amami-ôshima Is.).

Agelena opulenta L. Koch 1878

[Japanese name: Ko-kusa-gumo]

(Figs. 7-8, 19-20, 37-38)

Agalena opulenta L. Koch 1878, p. 757, pl. 15, fig. 20. [type not examined].

Agalena japonica Karsch 1879, p. 98, pl. 1, fig. 17 [syntypes, a
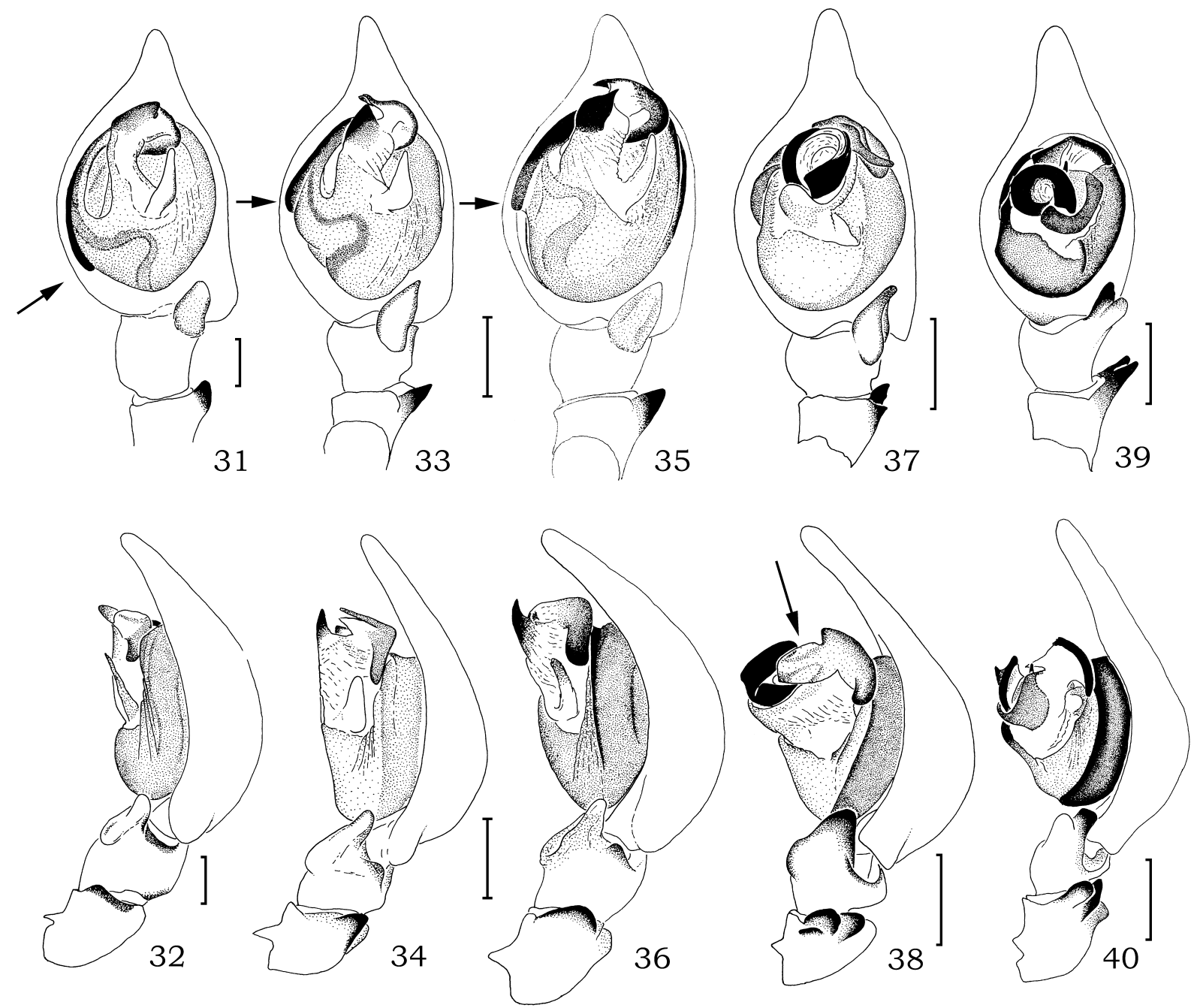

Figs. 31-40. Male palp, odd number ventral view, even number lateral view. - 31-32, Agelena limbata (Thorell 1897)(NSMT-Ar 5623); 33-34, A. labyrinthica (Clerck 1757)(NSMT-Ar 5642); 35-36, A. babai new species (NSMT-Ar 5650); 37-38, A. opulenta Koch 1878 (NSMT-Ar 5657); 39-40, A. donggukensis Kim 1996 (NSMT-Ar 5666). (Scales: 0.5 mm) 
female and a male, Japan, Dönitz leg., preserved in Museum für Naturkunde, Berlin, ZMB 2897, examined].

Agelena japonica: Bösenberg \& Strand 1906, p. 297, text-fig. 6; Saito 1959 , p. 37 , pl. 1, figs. 12 b-c, pl. 2, fig. 12 a, text-fig. 2.2 .

Agelena opulenta: Bösenberg \& Strand 1906, p. 298, pl. 16, fig. 467; Yaginuma 1958, p. 72; Saito 1959, p. 38, pl. 1, figs. $14 c^{-}$f, pl. 2, figs. $14 a^{-}$b, text-fig. 2.5; Yaginuma 1960 , p. 91 , pl. 42, fig. 239, text-figs. 81.4, 6; Paik 1978, p. 325, fig. 142. 1, 4 (part, male); Yaginuma 1986, p. 138, pl. 40, fig. 2, textfig. 73.3; Chikuni 1989, p. 98, fig. 2; Song, Zhu \& Chen 1999, p. 354, figs. 205L, 206I-J; Kim \& Tak 2001, p. 123, figs. $8 b^{-}$c (part, male); Namkung 2002, p. 362, unnumbered figs.

Specimens examined. MIYAGI PREF.: Lake Izunuma, Hasama-cho, 1ㅇ, 22-IX-1985; 10 , 23-IX-1985 (NSMT-Ar 5652); 10, 21-VIII-1986; 2우, 8-IX-1986; 1우2 즈, 23-IX1986; 1우, 10-X-1986; 1우, 26-X-1986 (NSMT-Ar 5653); 3 우주, 15-IX-1987 (1 ${ }^{\star}$ : NSMT-Ar 5654); Lake Uchinuma, Hasama-cho, 4우, 31-VIII-1985. IBARAKI PREF.: Tsukuba-shi, 2우주, 11-IX-1977. SAITAMA PREF.: Kinchakuden, Hidaka-shi, 1우, 13-X-1991. TOKYO: Tanashi-shi, 10 ${ }^{\lambda}$, 15-X-1995; Hachioji-joshi, Hachioji-shi, 2 우, 22-X-1989; Itsukaichi-cho, Nishitama-gun, 1우, 18- $\mathrm{X}^{-}$ 1992; Izu-ôshima Is., 1우, 26-X-1975, T. Takai leg. (NSMT-Ar 5655); detail uncertain, 10, 25-IX-1975, T. Takai leg. KANAGAWA PREF.: Izumi-ku, Yokohama-shi, 107, 19-VIII-1998; Maioka-cho, Totsuka-ku, Yokohamashi, 1우, 13-IX-1980, 1ㅇ, 18-IX-1982; Totsuka-ku, Yokohama-shi, 1우, 19-IX-1998; Noba-cho, Yokohama-shi, 13, 6-IX-1979, H. Iijima leg.; same locality, 1우, 1-X1979, M. Mori leg.; Mt. Enkaizan, Yokohama-shi, 1우, 27X-1985; Jinmuji, Zushi-shi, 1우, 21-X-1990, S. Tazoe leg. (NSMT-Ar 5656); Anjinzuka, Yokosuka-shi, 2우, 27- $\mathrm{X}^{-}$ 1996; Yokoyama-kyuryo-ryokuchi, Sagamihara-shi, 1우추, 1-X-2004 (10': NSMT-Ar 5657); Dôhogawa Park, Sagamihara-shi, 20, 10-IX-2004; 1우, 25-VIII-2004; Near Shimomizo Station, Sagamihara-shi, 2ㅇ, 25-IX-2004; 2 우2 ऽ, 27-X-2004; Tsukimino, Yamato-shi, 2워주, 30-VIII1993 (1우: NSMT-Ar 5658); 1우, 23-IX-1993; 3우, 24-X1993; Izumino-mori, Yamato-shi, 2우, 11-X-1992; Kamiwada, Yamato-shi, 1ㅇ, 30-VIII-1993; 2ㅇ, 24-X-1993; Yamato-shi, 1우, 30-VIII-1993; 13우, 24-X-1993 (1우: NSMT-Ar 5659); Zama-shi, 1우, 14-X-2000; Tsukuishiroyama, Tsukui-machi, 1우수, 10-IX-1989; Miyagase, Kiyokawa-mura, 1웋ㅈ, 9-X-2000 (1 ${ }^{\star}$ : NSMT-Ar 5660); Okura, Hadano-shi, 1우 18-X-1987; Oiso, Oiso-cho, 1우, 13-X-1985. SHIZUOKA PREF.: Minamiizu-cho, 2우호, 19-X-1986 (10: NSMT-Ar 5661); OKAYAMA PREF.: Okuichi, Okayama-shi, 2우, 2-X-1990. KAGAWA PREF.: Kokubunji-cho, Ayauta-gun, 2우, 3-X-1990; EHIME PREF.: Dôgo Onsen, Matsuyama-shi, 1우, 4-X-1990; Taihô-ji, Kumakôgen-cho, Kamiukena-gun, 1웇, 24-IX1971, N. Tsurusaki leg.

Description. Measurements (in mm). Based on 1우1 $\sigma^{ }$ from Miyagi Pref. (NSMT-Ar 5658, 5654), measurements in parentheses indicate the range among specimens. Body 우10.13 (6.77-13.25), 38.50 (7.31-10.88) long. Carapace 우.50 (2.83-4.94), 33.80 (3.64-4.82) long; 우3.45 (2.13$3.71)$, $22.84(2.84-3.71)$ wide. Length of legs [female/ male; tarsus + metatarsus + tibia + patella + femur $=$ total $]: \mathrm{I}$, $2.18+4.35+4.00+1.71+4.76=17.00 / 2.35+4.59+4.12$ $+1.47+4.53=17.06 ;$ II, $2.00+4.06+3.65+1.65+4.53$ $=15.89 / 2.24+4.29+3.65+1.41+4.29=15.88 ; \quad$ III, 1.88 $+4.06+3.18+1.47+4.29=14.88 / 2.00+4.18+3.24+$ $1.24+3.88=14.54 ;$ IV, $2.35+6.00+4.41+1.65+5.29=$ $19.70 / 2.41+5.88+4.24+1.35+4.82=18.70$. Abdomen 우6.00 (3.95-9.10), 3 4.76 (3.56-6.23) long; 우3.33 (2.50$6.00), 32.35$ (2.12-3.23) wide.

Female and male. Carapace longer than wide [length/ width $+1.30(1.30^{-1.33), ~} \overbrace{}^{\top} 1.34(1.28-1.34)]$. Median ocular area longer than wide [length/width +1.05 (1.05-1.15), ${ }^{\top} 1.06\left(1.06^{-1.12)}\right.$ ]; almost same width as in front as behind [anterior width/posterior width 우1.03 $\left(0.96^{-1.03), ~}{ }^{\top} 1.06\right.$ $(1.00-1.06)]$. Promargin of chelicera with 933,33 teeth, retromargin with o+5 $(3-5)$, ${ }^{\star} 5\left(3^{-5}\right)$ teeth. Labium wider than long [length/width 우 $0.74(0.71-0.81), \delta^{\top} 0.80\left(0.78^{-}\right.$ $0.82)]$. Sternum almost as long as wide or slightly longer than wide [length/width 우1.10 $\left(0.95^{-1.15}\right)$, o $^{\top} 1.10\left(1.02^{-}\right.$ 1.12)]. Length of leg I/length of carapace +o 3.78 (3.173.78), ${ }^{7} 4.49$ (4.37-4.66). Male palp (Figs. 37-38): embolus makes a circle, conductor with broad spatula in lateral view (Fig. 38, arrow). Abdomen longer than wide [length/width 우1.80 (1.52-1.80), 322.03 (1.68-2.03)]. Epigynum (Figs. 19-20): opening slightly wider than long, rim thick.

Coloration and markings. Female and male (Figs. 7-8). Carapace yellow with a pair of dark brown longitudinal lateral band. Dorsum of abdomen brown with a pair of dark brown longitudinal lateral bands including light colored markings.

Remarks. Agelena opulenta closely resembles $A$. donggukensis in general appearance, but can be easily distinguished from the latter by the shape of female epigynum and male palp. The epiginal rim is thick in opulenta (Fig. 19), thin in donggukensis (Fig. 21, 26-27); in lateral view, conductor of opulenta with spatular appendix (Fig. 38, arrow), but not in donggukensis (Fig. 40).

Distribution. Japan (Hokkaido, Honshu, Shikoku, Kyushu, Tokara Isls.), China, Korea, Taiwan.

Agelena donggukensis Kim 1996

[Japanese name: Hime-kusa-gumo]

(Figs. 9-10, 21-22, 26-27, 39-40)

Agelena donggukensis Kim 1996, p. 1, figs. 1-5; Kim \& Tak 2001, p. 116, figs. 3a-e.

Specimens examined. AOMORI PREF.: Momoishimachi, Kamikita-gun, 10, 17-VIII-2004; MIYAGI PREF.: Lake Izunuma, Hasama-cho, 1우, 1-IX-1985 (NSMT-Ar 5662); 4우, 22-IX-1985 (1우: NSMT-Ar 5663); 1우, 23-IX- 


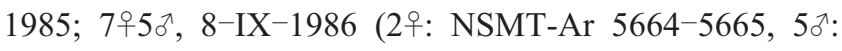
NSMT-Ar 5666-5670); 1우, 21-VIII-1986 (NSMT-Ar 5671); Lake Uchinuma, Hasama-cho, 3우, 31-VIII-1985. IBARAKI PREF.: Tsukuba-shi, 2ㅇ, 11-IX-1977. KANAGAWA PREF.: Asahi-ku, Yokohama-shi, 1우, 20IX-1997; Maioka-cho, Totsuka-ku, Yokohama-shi, 2우, 6IX-1986 (NSMT-Ar 5672-5673); Miyagase, Hadano-shi, 1 우, 9-X-2000.

Description. Measurements (in mm). Based on 1 우1 $\sigma^{7}$ from Miyagi Pref. (NSMT-Ar 5664, 5666), measurements in parentheses indicate the range among specimens. Body 우 9.00 (7.50-11.13), $38.25\left(7.00^{-} 8.80\right)$ long. Carapace 우 3.33 (3.33-4.23), $3^{7} 4.14\left(3.45^{-4.52)}\right.$ long; 우 2.43 (2.43$3.05)$, $33.05(2.59-3.29)$ wide. Length of legs [female/ male; tarsus + metatarsus + tibia + patella + femur $=$ total]: I, $1.60+2.92+2.68+1.20+3.28=11.68 / 2.73+6.27+5.67$

$+1.80+5.93=22.40 ;$ II, $1.44+2.56+2.32+1.16+3.08$ $=10.56 / 2.40+5.33+4.67+1.67+5.13=19.20 ; \quad$ III, 1.24 $+2.52+2.00+1.04+2.84=9.64 / 2.00+4.53+3.40+1.40$ $+4.47=15.80 ; \quad$ IV,$\quad 1.56+3.84+2.84+1.16+3.72=$ $13.12 / 2.40+6.13+4.47+1.47+5.40=19.87 . \quad$ Abdomen 우.93 (4.09-7.25), उ3.91 (3.64-4.24) long; 우3.67 (2.554.67), उ2.23 (2.09-2.76) wide.

Female and male. Carapace longer than wide [length/ width 우1.37 (1.33-1.39), ơ1.36 (1.33-1.45)]. Median ocular area longer than wide [length/width 우1.11 (1.03-1.13), ${ }^{1} 1.11\left(1.11^{-1.20)}\right.$ ]; wider behind than in front or almost same width [anterior width/posterior width $+0.93\left(0.76^{-}\right.$ $\left.1.03), \partial^{\top} 0.97(0.97-1.00)\right]$. Promargin of chelicera with 3 teeth, retromargin with $93\left(3^{-5}\right), 33\left(3^{-4}\right)$ teeth. Labium wider than long [length/width $+0.78\left(0.78^{-0.93),} \delta^{\top} 0.83\right.$ $(0.80-0.88)]$. Sternum slightly longer than wide [length/ width 우1.09 (1.09-1.19), ð 1.09 (1.09-1.15)]. Length of leg I/length of carapace 우3.51 (3.46-3.62), 355.41 (5.21-5.78). Male palp (Figs. 39-40): embolus makes a circle. Abdomen longer than wide [length/width 우1.62 (1.55-1.72), 万 1.76 (1.53-1.76)]. Epigynum (Figs. 21-22, 26-27): opening slightly wider than long, rim thin.

Coloration and markings. Female and male (Figs. 9-10). Carapace yellow with a pair of dark brown longitudinal lateral band. Dorsum of abdomen brown with a pair of dark brown longitudinal lateral bands including light colored markings.

Remarks. Agelena donggukensis closely resembles $A$. opulenta in general appearance. As for the discriminating points, see remarks of the latter.

Distribution. Japan (Honshu), Korea.

\section{Acknowledgments}

I wish to express my heartfelt thanks to Dr. Tadashi Miyashita, the University of Tokyo, for his critical reading of the manuscript of this paper. I am deeply indebted to Dr. Peter Jäger, Senckenberg Forschungsinstitut und Naturmuseum, Frankfurt am Main (SMF), Dr. Jason A. Dunlop, Museum für Naturkunde, Humboldt Universität zu Berlin (ZMB), and Dr. Mingsheng Zhu, Hebei University, for loaning invaluable specimens. My sincere thanks are also due to Dr. Nobuo
Tsurusaki, Tottori University, and Mr. Yuki G. Baba, the University of Tokyo, for offering the specimens used in this study.

\section{References}

Bösenberg, W. \& Strand, E. 1906. Japanische Spinnen. Abh. Senckenb. Naturf. Ges., 30: 93-422, pls. 3-16.

Blackwall, J. 1861. A history of the spiders of Great Britain and Ireland. London, 1: 1-174, pls. 1-12.

Chikuni, Y. 1989. Pictorial Encyclopedia of Spiders in Japan. 306 pp. Kaiseisha, Tokyo. (In Japanese)

Clerck, C. 1757. Svenska spindlar, uti sina hufvud-slågter indelte samt under några och sextio särskildte arter beskrefne och med illuminerade figurer uplyste. $154 \mathrm{pp}$. Stockholm.

Ishinoda, T. \& Tsukiji, M. 1969. "Spiders of Mt. Kirishima-yama." Kirishima-yama Sôgô Chôsa Hôkokusho, pp. 285-298. (In Japanese)

Karsch, F. 1879. Baustoffe zu einer Spinnenfauna von Japan. Verh. Naturh. Ver. Preuss. Rheinl. Westfal., 36: 57-105.

Kim, J. P. 1996. A new species of the genus Agelena (Araneae: Agelenidae) from Korea. Korean Arachnol., 12: 1-5.

Kim, J. P. \& Tak, H. K. 2001. A revisional study of the spiders family Agelenidae C. L. Koch, 1837 (Arachnida: Araneae) from Korea Korean Arachnol., 17: 111-139.

Koch, L. 1878. Japanesische Arachniden und Myriapoden. Verh. Zool.-Bot. Ges. Wien, 27: 735-798.

Lee, J. D. 1998. Agelena tungchis (Araneae, Agelenidae), a new funnel-weaver from Taiwan. Bull. Br. Arachnol. Soc., 11: 67-68.

Lehtinen, P. T. 1967. Classification of the cribellate spiders and some allied families, with notes on the evolution of the suborder Araneomorpha. Ann. Zool. Fenn., 4: 199-468.

Li, C. L. 1964. Spiders of Taiwan. 84 pp, 29 pls. Ta-chiang Publ., Taiwan. (In Chinese)

Namkung, J. 2002. The spiders of Korea. 648 pp. Kyo-Hak Publishing Co., Seoul. (In Korean)

Paik, K. Y. 1978. Araneae. Illustr. Fauna Flora Korea, 21: 1-548. (In Korean)

Roberts, M. J. 1985. The spiders of Great Britain and Ireland, Volume 1: Atypidae to Theridiosomatidae. 229 pp. Harley Books, Colchester, England.

Saito, S. 1939. On the spiders from Tôhoku (northernmost part of the main island), Japan. Saito Ho-on Kai Mus. Res. Bull., 18: 1-91, pl. 1.

Saito, S. 1959. The Spider Book Illustrated in Colours. 194 pp, 27 pls. Hokuryukan, Tokyo. (In Japanese)

Song, D., Zhu, M. \& Chen, J. 1999. The Spiders of China. 640 pp. 4 pls. Hebei Science and Technology Publishing House, Shijiazhuang.

Tanikawa, A. 2000. A check list of Japanese spiders (ver. 2000). Kishidaia, 78: 79-144. (In Japanese)

Thorell, T. 1897. Viaggio di Leonardo Fea in Birmania e regioni vicine. LXXIII. Secondo saggio sui Ragni birmani. I. Parallelodontes. Tubitelariae. Ann. Mus. Civ. Stor. Nat. Genova, (2) $17[=37]: 161-267$.

Yaginuma, T. 1958. Spiders from Shimokita Peninsula, Aomori Prefecture, Japan. Misc. Rep. Res. Inst. Nat. Resour. Tokyo, 46/47 69-77. (In Japanese with English description)

Yaginuma, T. 1960. Spiders of Japan in Colour. 186 pp., 56 pls. Hoikusha, Osaka. (In Japanese)

Yaginuma, T. 1985. Taxonomic notes on some Japanese spiders (Agelena, Dolomedes, Araniella, Araneus, Clubiona, Titanoeca). Fac. Let. Rev. Otemon Gakuin Univ., 19: 121-134. (In Japanese)

Yaginuma, T. 1986. Spiders of Japan in Color (n. ed). 305 pp., 64 pls. Hoikusha, Osaka. (In Japanese)

Received April 18, 2005 / Accepted May 16, 2005 